DOI https://doi.org/10.18551/rjoas.2018-11.17

\title{
THE ANALYSIS OF MARKETING STRATEGY AND PLAN OF PT. FOUR JAFFE INDONESIA
}

\author{
Mardianto Daniel \\ Master of Management Program Economics and Business, \\ University of Esa Unggul, Indonesia
}

\author{
Ramdhani Dadan \\ Faculty of Economics and Business, University of Sultan Agung Tirtayasa, Indonesia
}

*E-mail: danielmardianto@yahoo.co.id

\begin{abstract}
As a manufacturing company of effervescent tablet coffee Kopita, it requires the right marketing strategy to get into the target market. To ensure the proper implementation of marketing strategies in marketing products owned by PT. Four Jafe Indonesia, marketing framework or the process of preparing marketing plan and strategy must first be made. A good marketing plan and strategy will achieve the marketing objectives so that there is a balance between the product and the target market. Products, to be sold to the market, show an increase in sales volume, provide customer satisfaction, and achieve optimal profitability based on the expectations of the company. The aims of this analysis were to know marketing plan and strategy performed by PT Four Jaffe Indonesia. Based on the results of the analysis, the plans performed by the company included the determination of: marketing goals and objectives, market research, market situation analysis, market attractiveness analysis, and six market domain analysis. The strategies performed in running the company were segmenting, targeting, positioning, marketing tactics, marketing mix, customer relationship management, blueprint sales, customer results, company results, marketing budgeting, and sales estimates.
\end{abstract}

\section{KEY WORDS}

Marketing, strategy, coffee, sales, customer.

Indonesia is one of the largest coffee producing countries in the world, after Brazil and Columbia. Most of the coffee production goes into export trade whose export destinations include the United States, Germany, Japan and Singapore. Indonesian coffee plantation in 2016 was 1,233,294 ha and Indonesian coffee production was 667,655 tons. Most of the production is robusta coffee. Robusta coffee production reached 492,333 tons $(87.1 \%)$ of total Indonesian coffee production (Director General of Plantation, 2016).

Coffee is a refreshing drink consumed by some people while relaxing or during breaks at seminars and meetings (as a coffee break). Most people who consume coffee aim to extend the waking time by stimulating the central nervous system. In addition, consuming coffee can increase the power of thought and memory, increase alertness, increase the rate of reading, make the body not easily tired or sleepy and make the body become more passionate. This effect is produced by caffeine compounds in the coffee, (Van Dam and Hu, 2005). In the world of medicine, caffeine is used as a mixture of drugs including the medicine of cold, headache, fever, and stimulant.

In the early stages of starting the business world, prospective entrepreneurs should understand well about the ins and outs of marketing in a comprehensive and systematic way. The company will continue to grow, excel and become larger by taking strategic steps, including put the customer as the key of the company's success in improving extension and competitive advantage so that the product will be accepted and marketable (Barney, 2014). Presenting the quality of service and continuous achievement must be performed to be useful, superior to the customers and can compete with other competitors. 
Moreover, the business environment conditions are constantly changing due to the interest rate and the level of competition with other companies in grabbing a tight and highly competitive market share (hypercompetition) (D'aveni, 2010). Efforts in creating demand and marketing the product is one of the key successes of an organization in business matters. Marketing activities can be a source of company failure or it could be a waste if it is not properly planned. Many middle-scale entrepreneurs often have difficulty in formulating a formal marketing program, so that the resulting product is not able to match the expected target market, (Oh and Jeong, 1996).

From the above brief description, it can be concluded that the importance of marketing plans and strategies are mature, detailed and measurable. A good marketing plan and strategy will achieve the marketing objectives so that there is a balance between the product and the target market. Products, to be sold to the market, show an increase in sales volume, provide customer satisfaction, and achieve optimal profitability based on the expectations of the company.

As a manufacturing company of effervescent tablet coffee Kopita, it requires the right marketing strategy to get into the target market. To ensure the proper implementation of marketing strategies in marketing products owned by PT. Four Jafe Indonesia, marketing framework or the process of preparing marketing plan and strategy must first be made. The process of developing such marketing plans and strategies relates to the analysis of the business environment. The implementation process of marketing strategy of PT. Four Jafe Indonesia is related to the operational and financial strategies of the company which is supported by the proper management of human resources in achieving the company's goals.

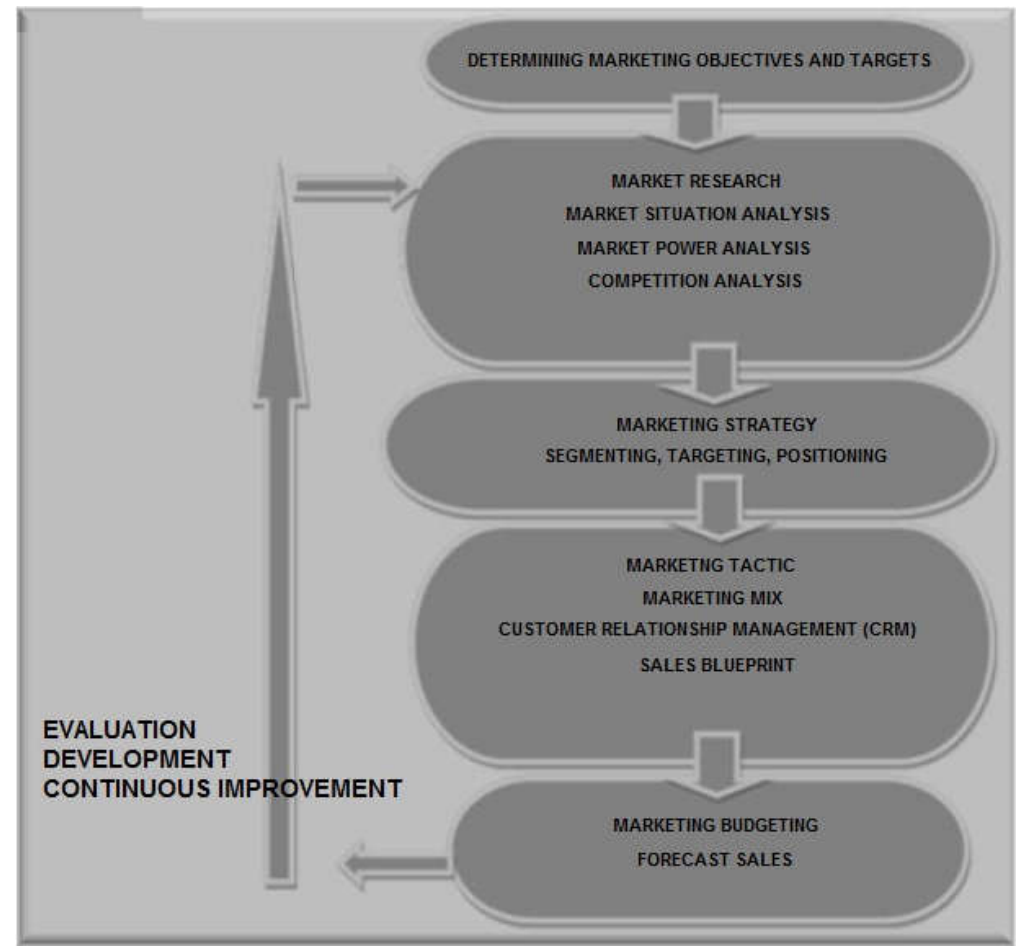

Figure 1 - The Marketing Framework of PT. Four Jaffe Indonesia

Framework or Marketing Framework of PT. Four Jaffe Indonesia as set forth in Figure 1 above aims to facilitate the marketing department in implementing work projects to achieve the goals of the company.

Determining the Objectives. The first marketing strategy is to determine the company's marketing objectives. The general purpose of marketing of a company is to strengthen brand loyalty, build brand awareness in the minds of customers, foster and build sustainable relationships with customers by providing excellent service in order to create loyalty to the company that eventually achieved sales targets. Marketing objectives, to be achieved by 
sales and marketing departments for effervescent tablet coffee Kopita products of PT. Four Jaffe Indonesia should be synergistic with the vision, mission and strategy set by the company. The first objective of the next 5 years is to become a market leader for coffee products that have competitive advantages both in the presentation and taste with market penetration which is prioritizing promotions, spreading initial sales in Jakarta, Bogor, Depok, Tangerang and Bekasi (Jabodetabek). In addition, it is to have a strong distribution channels and build strong brand awareness and create brand loyalty. The marketing objectives of PT. Four Jaffe Indonesia consist of short-term, medium-term and long-term goals.

The marketing target of PT. Four Jaffe Indonesia is to get $75 \%$ brand awareness for business to business and $70 \%$ for business to consumer in the $3^{\text {rd }}$ year, to reach $5 \%$ of market share in $3^{\text {rd }}$ year and $10 \%$ in $10^{\text {th }}$ year, to reach target sales growth in line with the target; $3^{\text {rd }}$ year by $29 \%$, the $4^{\text {th }}$ year by $20 \%$ and the $5^{\text {th }}$ year by $25 \%$ with an average growth of $20 \%$ each year and to achieve market retention by $80 \%$.

Market research is very important in which it is performed by gathering information about the market and analyzing the marketing context of the product; such as providing a description of the market, monitoring how the market is changing, determining the actions to be taken by the company and analyzing the results of those activities (Subagio, 2010).

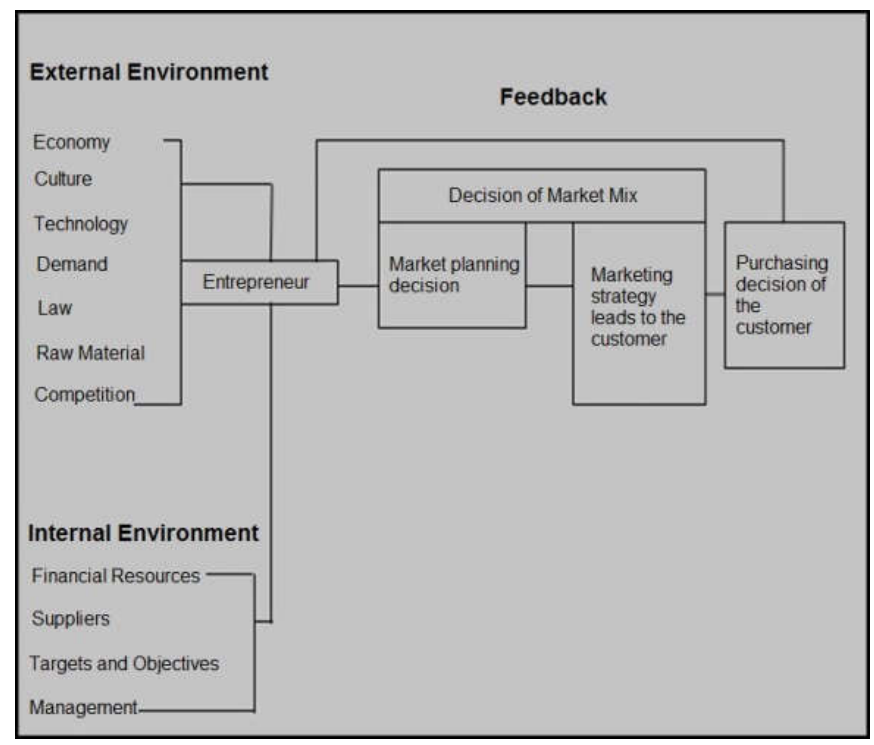

Figure 2 - Market Research inside and outside the Company

Before the company penetrates and implements marketing strategy, the company initially analyzes the market situation by mapping the market area, market potential and market picture. Then, the company analyzes the market attractiveness and ultimately conducts a competitive analysis to find out the market share and competitor's strength. PT Four Jaffe Indonesia must know and understand the marketing environment of the products offered by ensuring that the products are acceptable to the market (customers). The marketing environment consists of two factors of force: the internal force factor of the company (the instant coffee business) and the external force factor of the company (powers outside marketing) that affect the marketing management's ability to develop and sustain successful transactions on its target customers.

The most important thing in determining the right and strategic marketing strategy for PT Four Jaffe Indonesia is an analysis of market attractiveness and analysis of competitive advantage. This strategic marketing strategy will be the main thing before the company chooses the right marketing activity. Therefore, it can be more focused and targeted in maximizing marketing activities to the customers.

There are three dimensions that affect the attractiveness of the market forces, competitive intensity, and market access (Best, 2005). Analysis of market attractiveness is useful to see how attractive the market that will be targeted by PT Four Jaffe Indonesia. The 
following is the analysis of the three dimensions that affect the market attractiveness of manufacturing industry effervescent coffee Kopita.

To help the organization of PT Four Jaffe Indonesia (PT.FJI) to study the key stakeholders and the market domains, the authors add an analysis of 6 market models (Six Market Domain Analysis) taken from the literature (Lindgreen, 2004). It mentions that if an organization wants to grow and survive, it must maintain its relationship with the internal and external environment. Through analysis of all 6 markets, the managers may prefer critical markets and opportunities in every market. To visualize and understand the interests of each market, Payne and Holt (2001) provide 6 market models: Customer Markets, Influence Markets, Referral Markets, Supplier Markets, Recruitment Markets, and internal Markets.

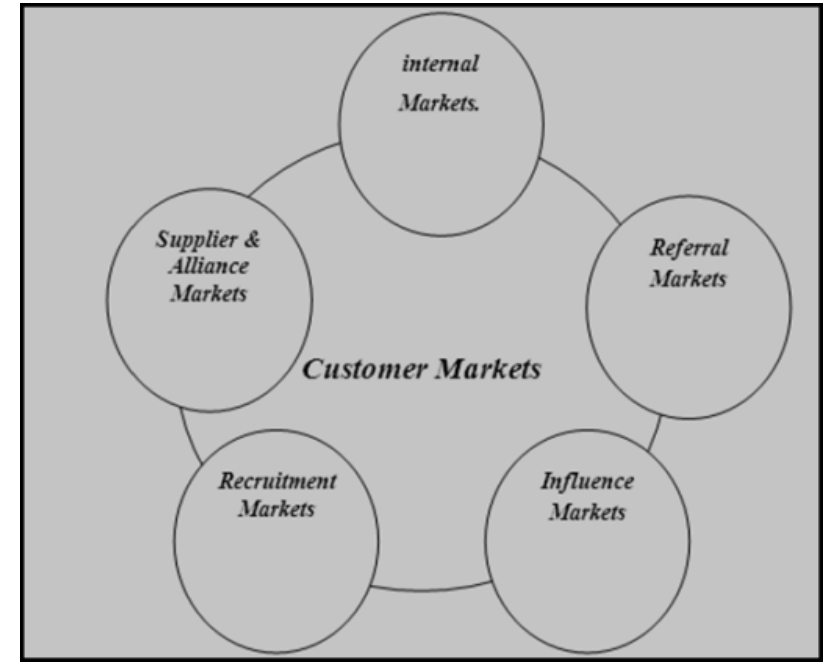

Figure 4 - The Six Market Domains (Source: Payne and Holt, 2001)

Marketing Strategy. In order to optimize the sales of effervescent coffee Kopita, to grow and meet the company's target, PT Four Jaffe Indonesia must implement an appropriate and good marketing strategy in the expectation of optimizing its marketing resources in order to achieve sales according to the established growth and target and to achieve sustainable competitive advantage.

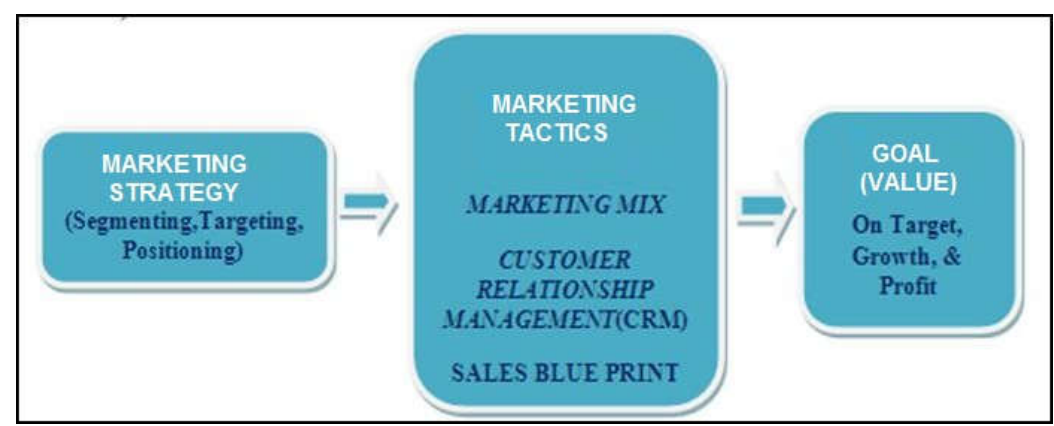

Figure 6 - Stages of Marketing Strategy

For the next step, the marketing strategy is segmentation, targeting, and positioning the product in the position based on the company's preference (positioning). Product positioning step is very important as the act of designing the offer and the image of the company in order to reach a special and unique place in the mind of the target market. Thus, it is expected to be a sustainable competitive advantage over competitors who eventually became market leader of instant coffee. After that, it performes a marketing tactic based on Marketing Mix (Marketing Mix) which is applied with Networking, Interaction, Common Interest, Experience (NICE Marketing). PT Four Jaffe implements $30 \%$ of Business to Business (B2B) market 
share and $70 \%$ on Business to Customer (B2C) market share. So, the application of marketing mix will be applied with NICE marketing tactics (Networking, Interaction, Common, Interest, Experience). The next marketing strategy is building marketing relationship that focuses on customer relations management (CRM) as a way of customer marketing that enhances the company's long-term growth and is an approach that emphasizes the effort of attracting and retaining customers through enhanced company relationships with its customers.

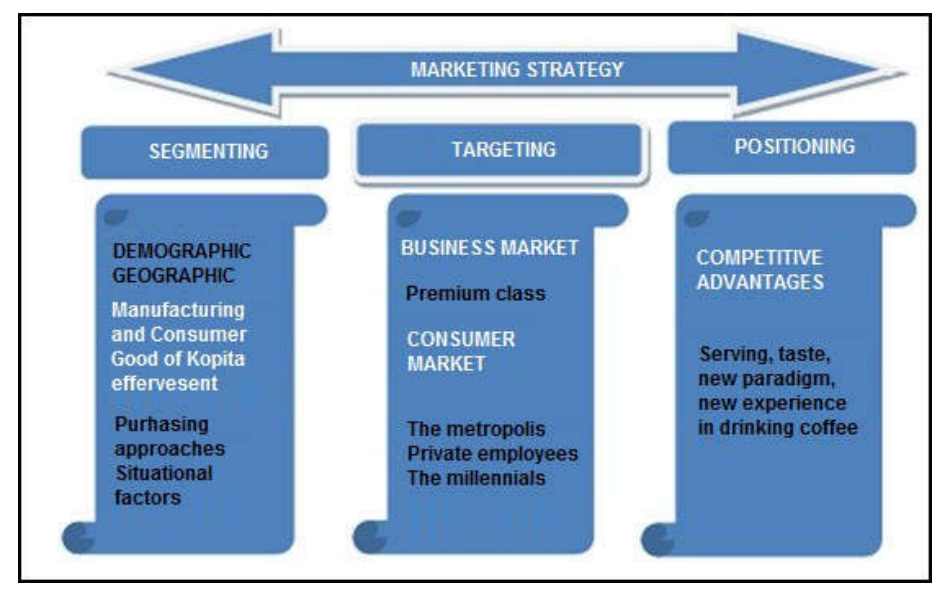

Figure 7: Marketing Strategy of PT FJI

Market segmentation is an attempt to segregate markets in heterogeneous purchasing groups in terms of interests, purchasing power, geography, buying behavior and lifestyles (Kotler, 2007). In addition, market segmentation, according to Kotler, Bowen \& Makens (1999) should meet criteria that can be measurable, accessible, large enough (substantial), differentiable and actionable. Market segmentation can be intended as a heterogeneous market division into homogeneous market groups, where each group can be targeted to market a product according to the needs, desires, or characteristics of consumers in the market. The target market is the business market so that segmentation is done using the criteria of business market segmentation. Business market segmentation is divided into five variables: demographic variables, operating variables, purchasing approaches, situational factors and personal characteristics (Kotler \& Keller, 2003). Business market segmentation criteria which are selected by PT Four Jaffe Indonesia use demographic variables, operating variables, purchasing approaches, situational factors and personal characteristics.

Targeting is the process of evaluating and selecting one or more of the most appealing market segments to be served with a company-specific marketing program. According to Kotler \& Armstrong (1997), targeting is a group of buyers who have the same needs or characteristics of the sales objectives. Targeting is a very important process because it will determine who will buy the product from the company. Targeting is to target the selected market in market segmentation analysis. PT FJI plans short-term sales targets $\left(1^{\text {st }}\right.$ year to $3^{\text {rd }}$ year) by estimating sales according to the initial forecast of 188,400 bottles per month or IDR $3,768,000000$ in rupiah and will be increased according to the expected growth (Table of Sales Plan of Tablet Coffee Kopita).

Table 1 - Target Determination of Business Market

\begin{tabular}{|l|l|l|}
\hline \multicolumn{1}{|c|}{ Description } & \multicolumn{2}{|c|}{ Target segmentation of the business market } \\
\hline \multirow{2}{*}{ Industry } & $\begin{array}{l}\text { Retail (B2C) } \\
\text { Modern Market }\end{array}$ & Distributor and wholesaler (B2B) \\
\hline \multirow{2}{*}{ Location } & JOBODETABEK & JABODETABEK \\
& $\begin{array}{l}\text { Serang City } \\
\text { Cilegon City }\end{array}$ & $\begin{array}{l}\text { Serang City } \\
\text { Cilegon City }\end{array}$ \\
\hline \multirow{2}{*}{ Purchasing Approaches } & Serving, taste and price & $\begin{array}{l}\text { Quality and service } \\
\text { Excellent }\end{array}$ \\
\hline
\end{tabular}

Source: Analyzed data for the research (2018). 
Positioning is an action or steps from the manufacturer to design a corporate image and offer value where consumers within a particular segment understand and appreciate what a particular segment does as well as understand and appreciate what a company does; compared to its competitors. To be different by the customer, the products must have point of differences (POD). POD of effervescent Coffee Kopita produced by PT Four Jaffe Indonesia will be a competitive advantage to its competitors in effervescent factor which has the advantages in the speed of serving in various conditions of water temperature (heat, cold and normal water), reaction properties acid bases that improve the taste to become more delicious, and a new paradigm for coffee connoisseurs. Determination of marketing strategies is advantageous in enhancing competitive advantage to a sustainable and seize market share according to the target. Therefore, effervescent tablet coffee Kopita products can compete and be accepted by the market by the determination of segmentation, target, and measurable and achievable product position, and certainly profitable for the company (Profit Oriented) according to the mission and vision of the Company.

Marketing tactics based on the marketing mix will be implemented with Networking, Interaction, Common Interest, Experience (NICE Marketing) stages. PT Four Jaffe implements $30 \%$ of Business to Business (B2B) market share and $70 \%$ on Business to Customer (B2C) market share. Thus, the application of marketing mix will be applied with NICE marketing tactics (Networking, Interaction, Common, Interest, Experience). The next marketing strategy will build marketing relationship that focuses on customer relations management (CRM) as a customer marketing effort which will enhance the company's longterm growth and is an approach that emphasizes the effort to attract and retain customers through enhanced company relationships with its customers.

After implementing the marketing strategy through Segmentation, Targeting, and Positioning stages, the next step is to perform a more specific step; marketing mx. Marketing mix is a set of operational decisions regarding product decisions, price decisions, promotional decisions, and place decisions. According to Philip Kotler, marketing mix is a marketing tip that companies use to achieve marketing goals in the target market. PT Four Jaffe Indonesia, which has the largest market share in B2B, marketing tactics of $4 \mathrm{P}$ will be synergized with NICE marketing tactics: Networking (Place), Interaction (Promotion), Common Interest (Price), and Experience (Product). PT Four Jaffe Indonesia emphasizes the gradual growth achievement in line with the increasing demand of each marketing area of $3^{\text {rd }}$ year sales by $15 \%, 4^{\text {th }}$ year sales by $20 \%$ and $5^{\text {th }}$ year by $25 \%$. With average growth, it is expected to achieve a minimum value of $20 \%$ each year which requires effective and appropriate marketing tactics for marketing management.

The application of NICE's marketing tactics focuses on building good relationships with customers based on networking (place) strategy in which marketing strategy builds marketing network with customers, for example creating customer data base to facilitate companies in the distribution of Kopita.

Interaction strategy (promotion) is to conduct product promotion activities to customers by using promotion tools that are able to influence customer loyalty and also promote product brand so that the end users will be curious to find the sales place of Kopita effervescent product. The common interest (price) strategy is having competition and cheaper pricing than other competitors so that there is mutual benefits between suppliers and customers. In addition, experience strategy (product) is to offer effervescent coffee products practically in the serving, the sensation of good taste due to the influence of acid base from the effervescent so that customer loyalty is maintained and customer satisfaction is created. PT Four Jaffe Indonesia Marketing Mix strategy is needed in maintaining cooperation with stakeholders that support the sales and is in accordance with the target company that is determined the achievement of product targets (determination of the right product), price (product pricing), promotion (promoting activity to the right market target) and place (distribution system that supports market segmentation). Penetration market of PT Four Jaffe Indonesia was conducted in 2 segments; that is market penetration for direct sales to outlets (modern market store, Alfamart, Infomart) called Business to Customer (B2C) and market penetration by establishing partnership for product distribution and wholesalers who have 
their own sales force called Business to Business (B2B). The components of marketing mix strategy for business to customer are 4P (product, price, place, promotion). PT Four Jaffe Indonesia with the largest B2B market share, its 4P marketing tactics will be combined with NICE's marketing tactics of Networking (Place), Interaction (Promotion), Common Interest (Price), and Experience (product).

CRM is a process of acquiring, maintaining and improving profitable customers. The marketing approach, by building relationships with customers, has the potential to affect the customer's feelings toward the company's products and also in doing business with the company. In managing true customer relationships, PT FJI requires long-term strategies and processes that create long-lasting customer satisfaction, not solely because of low cost and low price, but because customers feel more comfortable in doing business with the company and also feel comfortable about the product the company. CRM aims to create customer value so that customers feel satisfied and can maximize profits for the company. In addition, he also gained a competitive advantage (comparative advantage) by paying attention to product quality in order to provide excellent satisfaction for customers. CRM marketing strategy is intended to create customer loyalty.

The implementation of CRM that is made by marketing management to business market customers through continuity marketing, one to one marketing and partnering (comarketing) can be seen in building a solid long-term relationship with customers which requires a concentrated effort from all employees and management to find out what satisfies customers and customers value.

Customer Relationship Marketing (CRM) performed by PT FJI focuses on customer relations, product orientation, high emphasis on service, high commitment from customers to the products offered by the company, and the attention of management and all employees on the quality of instant coffee products in satisfying the desires of the customers. Transaction relationships between wholesalers, sub-distributors, distributors and customers are sustainable and do not end once the sale is completed. In other words, it is a long-term partnership with customers and on an ongoing basis so it is expected to make a repeat business.

With a hyper competition and ever-changing business competition and an everexpanding marketing strategy, PT FJI requires determining the right marketing strategies in the face of rapidly changing business competition. To perform this, PT FJI must prepare a solid, productive, and innovative team in adapting the development of marketing. To achieve success in the sale of coffee tablet effervescent Kopita, the management department of marketing and sales of PT FJI will build a design for the success of the sales force (blueprint for building a winning sales force). With the design for success, sales management are expected to bring the marketing team of PT FJI in creating sales success in accordance with the expected target.

Success in sales requires a solid, strong and synergistic team in the company's vision and mission. The leadership factor in the organization of PT FJI also has a strong influence and must be able to mobilize the spirit, motivation and assist sales force in doing sales activities. The success of sales force in the sales activity of coffee tablet effervescent Kopita should prioritize excellent service so that customers are loyal to Kopita products. The dimensions that drive success in sales are structure and roles of sales force, sales people, activities, customer results, company results.

As a leader must be able to know the scope of strong information (customer research, customer determination, data, tools, and customer relationship management or CRM), goal setting and forecasting, improve management performance, and understand design and market area for market development.

The key to success in placing products in target markets is the ability to maintain quality and product leadership in accordance with customer expectations. Sales activities cannot be separated from emotional control or feelings. Therefore, great sales people are sales people who can be expert or master in managing and controlling emotions. Important points that need to be owned by sales people in sales activity of effervescent tablet coffee Kopita is first the assertiveness; the characteristic that enables sales people to move the 
sales situation forward without offending or frustrating the customer. This position of assertiveness can be passive in terms of patient service and aggressive in terms of encouraging customers to have an interest in being a loyal customer.

Next, the second is self-awareness that the sales people must be able to identify their emotions in the sales activity. Ease of utilizing these emotions helps in building strong customer relationships. The ability to control emotions will be able to influence the effectiveness of effervescent tablet coffee Kopita based on experience that has been done and expand the positive emotions that can help sales people in sales activities.

The third is empathy which includes the behavior of sales people to the mood and emotion of the customer which starts from listening and observing what is perceived by the customer. Sales people must be able to build customer trust by continuous communication where it can motivate customers to be more confident in the product of Kopita that can provide benefits for the customer themselves.

To achieve success in selling the product, customer response needs to be considered. To get a good response from the customers, marketing management of PT FJI needs to build deep customer relationships and customer trust. Building relationships with customers has the potential to build customer feelings and beliefs about products and companies, creating sustainable relationships and long-term relationships.

High customer retention minimizes customers from moving to competitors (high customer retention and low defection). Efforts made to avoid customers moving to competing products are timely product distribution, ensuring the supply of the product is always there, and maintaining the quality of the product. Customer loyalty (a loyal customer base) is obtained when customers get their wish and get good service from PT FJI.

In building a business, the main note of the marketing management is the result that will be achieved by the company. In achieving the results that is determined by the company, the concern is the sales target, the market share and profitability in the first year (YO), which then the sales growth of $20 \%$ will be projected annually. To achieve the sales target, marketing management seeks 5\% market share in the first year (Y0) and seeks to increase market share every year. It is to support the company's sales growth. Sales targets created by the company will generate a margin of revenue (profitability) of $25 \%$ of total net sales. In achieving company results at PT FJI, the company's management will build a firm and strong sales team so that they are able to compete with competitors. The achievement of sales activities requires some cost in which marketing management should make marketing budget.

The strategy of determining the amount of costs for marketing activities greatly affects the success of marketing. Budgets are considered to be effective if they have predictive predefined characteristics, communication channels, clear authority and responsibilities, timely and accurate information, overall compliance, clarity of information, and support within the organization of all related parties.

In making sales estimates, the company makes most-likely scenarios, either in the form of sales projection or net marketing contribution. To start the most-likely scenario the company must first determine the total market share in the market to be addressed. The following is the total market share of the market target:

Table 2 - Sales Estimate

\begin{tabular}{|c|c|c|c|c|c|c|c|}
\hline \multirow{2}{*}{ No } & \multirow{2}{*}{ Outlet } & \multicolumn{2}{|c|}{$\begin{array}{c}\text { The number of the } \\
\text { outlet }\end{array}$} & \multirow{2}{*}{$\begin{array}{c}\text { Product/ } \\
\text { Outlet } \\
\text { (bottle) }\end{array}$} & $\begin{array}{c}\text { Total/ } \\
\text { Outlet } \\
\text { (bottle) }\end{array}$ & $\begin{array}{c}\text { Selling out } \\
\text { (IDR) }\end{array}$ & Description \\
\cline { 2 - 7 } & Java & $\begin{array}{c}\text { Outside } \\
\text { Java }\end{array}$ & 12 & 79,200 & $1,584,000,000$ & - \\
\hline 1 & Alfamart & 6,600 & 4,400 & 12 & 79,200 & $1,584,000,000$ & - \\
\hline 2 & Indomaret & 6,600 & 4,400 & 12 & & & $\begin{array}{c}\text { Spreading } \\
\text { Promotion was }\end{array}$ \\
\hline 3 & $\begin{array}{l}\text { Spreading } \\
\text { promotion }\end{array}$ & - & - & - & 30,000 & $600,000,000$ & $\begin{array}{c}\text { conducted by MD, SPR, } \\
\text { and SPV }\end{array}$ \\
\hline
\end{tabular}


The sales projection is based on the total demand projection of coffee effervescent Kopita with the projection of market share of $5 \%$ in the first year and $7.4 \%$ in the fifth year. The market will grow by $20 \%$ based on the average retail growth. Price is based on customer price that has been set before.

Table 3 - Sales Target of Most-likely Scenario

\begin{tabular}{|c|c|c|c|}
\hline Year & Market Share & Sales Target & Projected Sales (IDR) \\
\hline Y0 & $5 \%$ & $1,130,400$ & $18,086,000,000$ \\
\hline Y1 & $5.6 \%$ & $2,260,800$ & $36,173,000,000$ \\
\hline Y2 & $6.1 \%$ & $2,599,920$ & $46,799,000,000$ \\
\hline Y3 & $6.8 \%$ & $3,119,904$ & $56,158,000,000$ \\
\hline Y4 & $7.4 \%$ & $3,899,880$ & $70,198,000,000$ \\
\hline Y5 & $8.2 \%$ & $4,679,856$ & $93,597,000,000$ \\
\hline Y6 & $9.0 \%$ & $5,147,842$ & $102,957,000,000$ \\
\hline Y7 & $9.9 \%$ & $5,611,147$ & $112,223,000,000$ \\
\hline
\end{tabular}

Source: Analyzed data for the research (2018).

\section{CONCLUSION}

The marketing objective of PT Four Jaffe Indonesia consists of short-term goals, medium-term goals and long-term goals. The marketing environment consists of two factors of force: the company's internal force factor (the instant coffee business) and the external force factor of the company (forces outside marketing) which affect marketing management's ability to develop and sustain successful transactions with its target consumers.

There are three dimensions that affect the market appeal including market forces, competitive intensity, and market access. Based on an analysis of all 6 markets, managers may prefer critical markets and opportunities in every market. To visualize and understand the interests of each market, Payne \& Holt (2001) provides 6 market models: Customer Markets, Influence Markets, Referral Markets, Supplier Markets, Recruitment Markets, and Internal Markets. To have effervescent coffee sales Kopita be right on the target, grow and meet the target company, PT Four Jaffe Indonesia must implement appropriate and good marketing strategies in order to optimize its marketing resources and achieve sales based on the established growth and targets and achieve sustainable competitive advantages.

After that, the company must do marketing tactics based on Marketing Mix which will be applied with Networking, Interaction, Common Interest, Experience (NICE Marketing). PT Four Jaffe implements $30 \%$ of Business to Business (B2B) market share and $70 \%$ of Business to Customer (B2C) market share. Therefore, the application of Marketing mix will be applied using NICE marketing tactics (Networking, Interaction, Common, Interest, Experience).

The business market segmentation criteria chosen by PT Four Jaffe Indonesia is using demographic variables, operating variables, purchasing approaches, situational factors and personal characteristics. PT FJI plans short-term sales targets (1st through 3rd year) by estimating sales for initial sales forecast of 188,400 bottles per month or IDR $3,768,000,000$ and will be raised according to the expected growth (Table - Sales Plan of Tablet Coffee Kopita).

Effervescent tablet coffee kopita products can compete and be accepted by the market with the determination of segmentation, targets, measurable and achievable product position and profitable for the company (Profit Oriented) which is based on the mission and vision of the company. Test marketing tactics based on Marketing Mix will be applied with Networking, Interaction, Common Interest, Experience (NICE Marketing) stages. PT Four Jaffe Indonesia applies the largest B2B market share so the 4P marketing tactics will be combined with NICE marketing tactics: Networking (Place), Interaction (Promotion), Common Interest (Price), and Experience (Product).

Customer Relationship Marketing (CRM) conducted by PT FJI focuses on customer relations, orientation to product benefits, high emphasis on service, high commitment from 
customers to the products offered by the company, and the attention of management and all employees to the quality of instant coffee products in satisfying customer desires. The dimensions that drive the success in sales are sales force, structure and roles, sales people, activities, customer results, company results.

An important point that sales people need to have in sales activity of effervescent tablet coffee Kopita is assertiveness, which is the characteristic that enables sales people to move the sales situation forward without offending or frustrating the customers. This position of assertiveness can be passive which means to patiently serve the customer, and the aggressive characteristic in terms of encouraging the customer so that they have an interest to be a loyal customer.

High customer retention will prevent the customers not to move to other competitors (high customer retention and low defection). Efforts that can be performed are timely distribution of products and ensure the supply of products is always there, and maintain the quality of the product. It is one way to avoid customers from moving to competing products. Customer loyalty is obtained when they get their expectation and get good service from PT FJI.

In achieving company results of PT FJI, the company's management will build a strong and firm sales team to compete with other competitors. The achievement of sales activities requires some cost then marketing management must create a marketing budget. The strategy of determining the amount of fees for marketing activities greatly affects the success of marketing. The budget is considered to be effective if it has characteristics including predictive capabilities, clear communication channels of authority and responsibility, timely and accurate information, overall compliance, clarity of information, and support within the organization of all related parties.

Projected sales, based on the projected total demand for effervescent tablet coffee Kopita with projected market share in the first year is $5 \%$ and $7.4 \%$ in the fifth year. The market will grow by $20 \%$ based on the average retail growth. Price is based on customer price that has been set before.

\section{REFERENCES}

1. Barney, J. B. (2014). Gaining and sustaining competitive advantage. Pearson higher ed.

2. Best, R.J. 2005. Market-based management: strategies for growing customer value and profitability - 4th ed. Upper Saddle River, N.J.: Pearson/Prentice Hall.

3. D'aveni, R. A. (2010). Hypercompetition. Simon and Schuster.

4. Direktorat Jendral Perkebunan, 2016, Statistik Perkebunan Indonesia Kopi 2014-2017, Jakarta

5. Kotler, P. \& Armstrong, G. 1997. Dasar - Dasar Pemasaran. Jilid 1. Jakarta: Prenhalindo.

6. Kotler, P. \& Keller, K. L. 2003. Membangun Minat Beli. Indeks.

7. Kotler, P. 2007. Manajemen Pemasaran. Jakarta: PT. Indeks.

8. Kotler, P., Bowen, J., \& Makens, J. 1999. Marketing for Hospitality and Tourism. Second Edition. Prentice Hall Inc. Upper Saddle River, New Jersey.

9. Lindgreen, A. 2004. The design, implementation and monitoring of a CRM programme: a case study. Marketing Intelligence \& Planning, Vol. 22 Issue 2, pp.160-186.

10. Oh, H., \& Jeong, M. (1996). Improving marketers' predictive power of customer satisfaction on expectation-based target market levels. Hospitality Research Journal, 19(4), 65-85.

11. Payne, A., \& Holt, S. 2001. Diagnosing Customer Value: Integrating the Value Process and Relationship Marketing. British Journal of Management, Vol.12, 159-182.

12. Subagio, A. 2010. Marketing In Business. Jakarta: Mitra Wacana Media.

13. Van Dam, R. M., \& Hu, F. B. (2005). Coffee consumption and risk of type 2 diabetes: a systematic review. Jama, 294(1), 97-104. 